\begin{tabular}{c} 
Volume and Issues Obtainable at Center for Sustainability Research and Consultancy \\
Journal of Business and Social Review in Emerging Economies \\
ISSN: 2519-089X (E): 2519-0326 \\
Volume 7: No. 1, March 2021 \\
ᄃSRᄃ \\
Journal homepage: www.publishing.globalcsrc.org/jbsee \\
\hline
\end{tabular}

\title{
Impact of Pakistan Bait-Ul-Mal on the Socioeconomic Conditions of the Beneficiaries
}

*Ume Laila, Public Policy, School of Social Sciences and Humanities (S3H), National University of Sciences and Technology (NUST), Islamabad, Pakistan

Najma Sadiq, Head of the Department, Department of Mass Communication, School of Social Sciences and Humanities (S3H), National University of Sciences and Technology (NUST), Islamabad, Pakistan Tahir Mehmood, Department of Communication studies, Bahauddin Zakariya University, Multan, Pakistan

Khansa Almas, Graduate Public Administration, Department of Government \& Public Policy, National University of Sciences and Technology (NUST), Islamabad, Pakistan

*Corresponding author's email address: dr.umelaila@s3h.nust.edu.pk

RTICLE DETAILS

History

Revised format: Feb 2021

Available Online: Mar 2021

\section{Keywords}

Social Conditions, Economic

Conditions, Welfare, Social

Welfare, Pakistan Bait-ul-

Mal.

JEL Classification

MO, M1

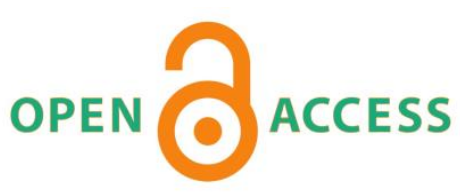

\section{ABSTRACT}

Purpose: This study aims to assess the socioeconomic conditions of the beneficiaries who are associated with Pakistan Bait ul Mal and are receiving funds. The target population of this research were the beneficiaries affiliated with the Pakistan Baitul Mal regardless of the fat that whether they have received the programs and services in the given time frame or not.

Methodology: The quantitative data collected was on the bases of telephonic surveys which targeted a total of 155 beneficiaries.

Findings: After a careful analysis of data, it was revealed that most of them agreed that these services have positively impacted on their socioeconomic conditions. The top three influencing factors in this study include the difficulty in application process, monthly household income and employment status.

Implications: The importance of poverty reduction programs along with other welfare plans as a stepping stone towards the most effective welfare state, the significance of Pakistan Bait-ul-Mal can't be denied and therefore the viability of a lawful sponsorship for such projects or organizations has for quite some time been perceived by the policy makers. The seriousness of the research further enhances because of the way that this subject had not been in the spotlight for quite a long time. Consequently, institutional re-building and approach corrections have not been much into training.

(C) 2021 The authors, under a Creative Commons AttributionNonCommercial 4.0

Recommended citation: Laila, U., Sadiq, N., Mehmood, T. \& Almas, K. (2021). Impact of Pakistan Bait-Ul-Mal on the Socioeconomic Conditions of the Beneficiaries. Journal of Business and Social Review in Emerging Economies, 7(1), 69-80. 


\section{Introduction}

"Power has only one duty - to secure the social welfare of the People." (Benjamin Disraeli). What makes poverty the most serious challenge we face? Socio-political and financial gaps have been extended by exposing the nation to various vulnerabilities at the national and sub-national levels due to the recurring natural disasters in recent history, including the 2010, 2012, and 2014 floods. As one might expect, improvement efforts have been sabotaged, and according to Abuturab Khans "Disaster management in Pakistan has not been very effective" (Abu, 2014). Moreover, the nation lingers behind significantly in terms of advancement targets, including the UN MDGs. Pakistan, like other developing nations of the world, is reliant on the agrarian economy due to low profitability and an alarming increment in population, per capita income. Pakistan ranks at 107 out of 134 nations (Bank, 2005). The nation following 58 years of its life, is still confronting the issues of weak socio-framework. Indeed, even now most of the indicators of prosperity, for example, proficiency, education, wellbeing, nourishment, safe drinking water, and sanitation, access to family benefits are quite low when compared to different nations with the same degree of per capita income.

Concerning the economic environment of the country, it is difficult to quantify its economic performance since different dimensional methodologies acknowledged at a worldwide level in this setting have not provided suitable expectation outcomes. In such startling conditions there rise complexities regarding the development process in order to address the needs of the concerned sectors as well as economic indicators to accomplish the stipulated goals.

Thus, all endeavors revolving around development related activities received in progressive Five-Year Plans, demonstrated failed leading towards the instability of the economic development of the nation. Pakistan's economy has been seriously impacted by the "War against terror" and by the downturn of foreign direct investment. We have seen that Pakistan's economy has a fluctuating growth rate. Such variations are due to several factors such as weak legal, governmental, and educational institutions, global conflicts, wars, and the global economic crisis.

Pakistan is a developing country with significant levels of poverty, poor health conditions, high illiteracy, low standard of living, and an uncontrolled population. Additionally, the financial and monetary policies being applied by the government are promoting the deterioration of the exchange rate, and this procedure of modification has caused tax hikes on utilization, cutbacks in public expenditure for improvement, and social administrations. This has at last converted into improved duties on public products and enterprises, for example, gas and power. Every one of these changes diminishes economic chances and expand the typical cost for living, which further brings down the standard of everyday living for poor individuals. Poverty is an inherent cause that negatively influences the pace of economic development and it is driven by differences in both capability and opportunity.

Poverty is a global trend that reflects extreme deprivation in the well-being of individuals. It exists where individuals are denied the resources to fulfill their fundamental needs for survival.

Poverty is a major concern in developing countries, especially in Pakistan, where a large portion of the population lives in extreme poverty. After Independence, Pakistan's economy was at a crucial stage, lacking the resources needed for its growth. It is generally assumed that the lower the national income or greater disparity in the distribution, the higher the rate of poverty. In Pakistan, the per capita national income level is low, there is a significant degree of disparity in economic livelihoods, a large amount of growing population with limited resources, a high rate of inflation and unemployment. All these conditions are responsible for the rise in poverty.

One third of Pakistan's population resides below the poverty line, as stated before this is due to a litany of reasons.

Access to education appears to be a major concern for Pakistan. There is an obvious rift in terms of 
the service being provided for education, which impacts the field negatively. Several factors ranging from socio-cultural to economic and even supply related impede access to education for several people, with adolescent girls being the worst off in this regard.

The hurdles that thwart efforts to reach the marginalized in society are varied and complex, they include: Insufficient financing, insubstantial policy regulations, and oversight, as well as an inability to implement resources and services equitably. There is an observable link to be made between the career paths of household heads and educational procurement regarding poverty rates of said households. One of Pakistan's major challenges has to do with its health sector. Gender disparity is yet another problem that poses Pakistan with a big challenge. Pakistan's gender disparity is 0.564 and places the nation 151 out of 153 countries (2019). There is a major wage gap present between females and males in Pakistan. Most females receive less monthly income than males in both Pakistan's urban and rural regions. There is an obvious deficiency regarding the country's employment statistics, which show a spectrum of male and female employees or entrepreneurs that is deemed to be the 'informal sector'.

Pakistan has no general or universal social security program which covers all its citizens. It does not even have an overarching organization that can expand financial insurance and social security networks to the vulnerable. However, NGOs, the government, and the private sector are adopting a range of initiatives aimed at strengthening the governance and accountability of public agencies to be able to adequately adapt to the needs of the underprivileged; supporting them economically by providing incentives for income and jobs, and enhancing their access to basic services.

\section{Pakistan Bait-ul-Mal}

The States introduce social safety net programs and systems which creates fairness and promotes equality among their citizens and provide equal opportunities for the growth. Such systems aim to eliminate poverty and assist their vulnerable community by providing them with cash transfers. These cash transfers are given based on any per-determined condition or direct transfers. This framework is generally oriented towards cash transfer and assistance programs.

Similarly, Islamic Welfare States also strives to increase social welfare and mobility by providing cash transfers and assistances to the vulnerable community through the government's treasury. In 1992, Pakistan introduced one such program known as Pakistan Bait-ul-mal. It is a social safety net program that contributes significantly to alleviate deprivation through its various projects. By supporting abandoned citizens and their families, PBM is moving on investing in projects that could eventually cause a long-term reallocation of capital and other services for the nation that could have the most significant effect on Pakistan's future. In the short run, it tries to minimize the impact of poverty by assisting the vulnerable for fulfilling their basic requirements. However, its main objective is to provides social protection to the deprived and poor communities.

Pakistan Bait-ul-Mal or PBM, a public treasury, was established in 1992 to advocate for poverty alleviation by focusing solely on widows, children, people with disabilities, the vulnerable and the disadvantaged, regardless of race, ethnicity, creed, or faith. This such public organization of Pakistan is tackling several different issues, be it around children, youth, women, as well as the welfare of the physically and rationally impaired. Furthermore, there is a focus on family planning, recreational projects planned to fend off individuals from anti-social exercises, social instruction(i.e. training of adults planned for creating a feeling of patriotism and responsibility), welfare and recovery of discharged detainees, and the welfare of adolescent delinquents.

Pakistan is one of the few developing countries whose constitution specifies, in article 38 (a) (d) \& (e),that social security is a clear constitutional right. Pakistan's constitution protects its people's 
fundamental right to social protection. To fulfill the commitment of this constitutional amendment, several social security and social assistance programs are being carried out and playing a key role in the country's poverty alleviation strategy. Pakistan's major social safety schemes are the structures of Zakat and Bait ul-Mal, social welfare organizations built based on Islamic Law. Though different in nature, the beneficiaries of these schemes have a similar purpose, i.e. providing financial assistance and recuperation for the poor, needy and the deprived.

Pakistan's Bait ul-Mal is a public sector organization at a national level. It was created as an autonomous body in February 1992 under the provisions of the Pakistan Bait ul-Mal Act of 1991. The Ministry of Social Welfare and Special Education carried out Bait ul-Mal Act with the aim of alleviating or at least reducing poverty as much as possible. The aim behind the establishment of this institution was to aid those groups of people who were excluded or were not eligible to receive zakat for certain reasons. This includes minorities and certain sects of Muslims. In fact, the service range was expanded and included citizens from all over the country including the Northern Areas and Kashmir.

The Bait-ul-Mal contributes greatly to deprivation alleviation through its various projects. The aim is based on encouraging reduction of poverty and sustainable growth. It offers financial help to the vulnerable where rehabilitation is the priority. The aim is to provide social protection to the poor, educational help to needy orphans, accommodation and necessary facilities to the deserving, medical treatment for sick by setting up free hospitals, financial help to charities and helps individuals to set up businesses. By supporting abandoned citizens and their families, Bait-ul-Mal is moving on investing in projects that could eventually cause a long-term reallocation of capital, talent and other services for the nation that could have the biggest positive effect on Pakistan's future.

The Bait ul-Mal operations are mainly funded through federal government grants. Small grants are often provided from the national zakat fund and from provincial and local governments. Funding from local authorities, regional governments, foreign agencies, and voluntary donations are also received. Funds can also be produced through the sale of the Bait-ul-Mal's property or assets.

The Federal Government forms a Board of Management for Bait ul-Mal administration. It consists of a chairperson, managing director, six non-official representatives selected from each province by the Federal Government, and one to represent Islamabad Capital Territory, Northern Areas and Azad Jammu and Kashmir, and three official members which are representatives of Ministry of Finance, Ministry of Religious Affairs and NADRA. At least one of the non-official members must be a woman. The current managing director of Bait-ul-Mal is Abbas Buppi, who was appointed by the Government in 2018.

\section{Literature Review}

Moving to health care services, Pakistan has a major issue in this regard, however it has taken steps to mitigate crises. Researchers have investigated different aspects like rural health financing where the correlations drawn are between rising medical expenses and notable decreases in public health service use along with increases in household income (Germano Mwabu and Joseph Wang'Ombe 1998). Similarly, we have research centered around family and health services where aspects like familyplanning, and maternal health are determined by socioeconomic factors. Research states that it is these factors and something like physical proximity that make a difference to people (N.P. Das, Vinod K. Mishra, and P. K. Saha 2001).In accordance with this, when it comes to health care utilization it has been noted that there is great inequality concerning access to public health services and one way to address the issue is by having NGO's and governments combine resources. In the meantime, people rely on private health care which is costly and varied in terms of quality. (Paul N. Mbatia and York W. Bradshaw 2003). Studies have also been conducted on health care services for low income groups (Rajeev Ahuja and Alka Naran 2005). There have been even more niche studies regarding this aspect including maternal health care service analysis where it has been concluded that modest funding can 
significantly enhance the experience. However, the use of the funds had to be monitored otherwise patients see fit to spend it however they like (Chava Kahn, Moses Iraguha, Moïse Iraguha, and Michael Baganizi et al 2015).

Financing is also an important aspect of welfare and as such several studies have investigated it such as whether it can improve overall efficiency and equity (John K. Hudzik 1985). Furthermore, when it comes to overall financial management shortcomings the following have been identified including inept revenue gathering, ineffective resource distribution, weak accounting system, and a service shortage via lack of funds (Edson MBEDZI and Tendayi GONDO 2010). Accordingly, it has been noted that there is no correlation between fiscal transfers and superior public service delivery, and they are mainly used for building purposes (Haiyan Duan and Jing Vivian Zhan 2011). Finally, when it comes to government spending/financing we can see that welfare suffers because of differing political agendas, fund wastage, and fiscal devolution trends (Gerrit J. Gonschorek and Gunther G. Schulze 2018).

Next we have welfare and education, as previously mentioned the idea of hereditary literacy is strong in Pakistan, and is something that has yet to be addressed properly. Several researches have been conducted on this factor such as an analysis on public education and social programs in 18 democratic nations where some regimes alternate between these two aspects as effective policy strategies since the 1960s (Gunther M. Hega, Karl G. Hokenmaier 2002). College financial aid was further investigated, one study suggested that by reducing 30\% of scholarships benefits were decreased and costs escalated (Bridget Terry Long 2004).Coming to gender dynamics and scholarships it is seen that men have to maintain grades while women do not (Rey Hernández-Julián 2010). However, when it comes to problems with education funding, we can see that it has to do with policy process changes (Erik C. Ness 2010). Furthermore, it has been documented that there is a positive correlation between merit awards and student performance (Shouping $\mathrm{Hu}$ 2011). It was also found that public administrators were less interested in policy processes concerning education (Junfeng Wang, Beverly S. Bunch and Christopher Stream 2013).Others call for further comparative research on education and the welfare state (Anne West and Rita Nikolai 2013). One of the most critical factors that were investigated was an analysis of free basic education (Andrew Rosser and Priyambudi Sulistiyanto 2013). Moreover, researchers also investigated how there is ineffective resource mobilization at a university level (Elisam Magara, 2015).Education funding is also investigated such as that of the (LPDP's) Indonesia Endowment Fund for Education (Fahdiansyah Putra, Rahmadi Diliawan, Abdul Rasyid Sahar Et al 2018).

Finally, in terms of Islamic principles we can see that an assessment into Muslim ideologies showed that principles like zakat, waqf, etc. not only freed slaves, protected the vulnerable, and expanded the health care system, it also launched humanitarian programs (Jamal Carafes 2005). With all these factors in mind it is easy to see why carrying out a wholistic representation of welfare can be difficult, but there are many commonalities that can be drawn, and it is through those that we can identify patterns of inefficiency, effectiveness, and potential improvements.

\section{Research Methodology}

The research aims to assess the impact of services of Pakistan Bait-ul-Mal on socioeconomic welfare of beneficiaries. The motivation which compelled us to carry out a research on this topic was the link that existed between what we are studying and the nature of the institution. The viability of the research has been enhanced with the fact that this study analyzes a public welfare institution based on impact assessment which investigates the following three aspects:

1. To evaluate impact, efficiency, and effectiveness

2. To identify shortcomings

3. To improve the programs \& institution

Two methods have been employed which include primary data and secondary data collection method. Primary data was collected through two ways, i.e. telephonic surveys and interviews. Surveys were used 
to generate the quantitative data by computing the details regarding the know-how of institutions, under which income strata can be characterized under the head of beneficiaries and most importantly what benefits were achieved from Bait-ul-Mal by the beneficiaries. The interviews and focus-group discussions were used to collect primary data regarding and helped to garner detailed and in-depth understandings as to how the Bait-ul-Mal targets the needy, and how efficient and effective the institution is when it comes to providing the services it claims.

For the collection of primary data, it required a subjective approach to identify the socio-economic condition of the beneficiary households were enhanced or diminished. The structured interview questions which were asked from the stakeholders of the Bait-ul-Mal and the focus group discussions carried out with executives, is attached in Annex. These exercises helped in analyzing the satisfaction level of recipients along with the efficiency and effectiveness of the Bait-ul-Mal.

For the purpose of secondary data, the beneficiaries 'records were acquired from Pakistan Baitul Mal, on special request. The PBM administration provided us contact information, personal information and service details of 1493 beneficiaries from the duration period $1^{\text {st }}$ April 2020- $30^{\text {th }}$ April 2020.

For this research random sampling was chosen for the selection of an area to study and the category of people to be surveyed. The reason for this choice was because it was the most widely used sample style. "random sampling is a subset of a statistical population in which each member of the subset has an equal probability of being chosen. A simple random sample is meant to be an unbiased representation of a group" (Adam, 2019). Through random sampling we were able to access different recipients from all over the Pakistan without confining our research to a specific area.

For primary data analysis simple rules of regression were employed and different statistical computation tools had been used to interpret the data. The method used to analyze the secondary data obtained, was content analysis. Content analysis enables the researcher to identify and investigate the real meaning and notion behind the words said by the interviewee. Furthermore, this analysis technique also evaluates the behavioral responses, determines the psychological and emotional well-being of the people and groups, and reveals any communication gaps that may exist. (mailman.columbia, n.d.) For the purpose of this research we used the relation content analysis. Moreover, relational content analysis allows a researcher to identify and, maintain a plausible link between what they intend to find, what they are looking for and what are the outcomes of their findings. (mailman.columbia, n.d.).

\section{Research Analysis \\ Quantitative Analysis}

\section{Social Impact of Poverty Alleviation Service}

We evaluated the poverty alleviation service in order to check the social impact of this service. In this relation all the results turned out to be highly significant because most of the beneficiaries had lost their jobs amid COVID-19 and they were in dire need of the financial support. With the timely disbursement of the funds the beneficiaries were quite satisfied. From the table following the results can be seen.

Table 1: Poverty Alleviation- Social Impact

\begin{tabular}{|c|c|c|c|}
\hline \multicolumn{4}{|c|}{ DEPENDENT VARIABLE } \\
\hline \multicolumn{4}{|c|}{ POVERTY ALLEVIATION SERVICE AVAILED } \\
\hline 1 & 2 & 3 & 4 \\
\hline & $\begin{array}{l}0.0157 * * * \\
(0.0123) \\
-0.102 * * * \\
(0.042)\end{array}$ & $\begin{array}{l}0.1050 * * * \\
(0.1236) \\
-0.102 * * * \\
(0.0428)\end{array}$ & $-0.666 * *$ \\
\hline
\end{tabular}




$\begin{array}{lllll} & & & (0.0392) \\ \text { Age } & 0.044^{* *} & & 0.037^{* *} \\ & (0.0154) & & (0.0152) \\ \text { Gender } & -0.1874 * * & & -0.1342^{* * *} & \\ \text { Employment status } & (0.0954) & & (0.0966) & \\ \text { Marital status } & & -0.047^{* * *} & -0.055^{* * *} & \\ \text { Ethnicity } & & (0.038) & (0.0382) & \\ & & & 0.050^{* * *} & \\ & -0.014 * * & & (0.0627) & -0.066^{* *} \\ & (0.038) & & & (0.0381)\end{array}$

The values represent that the relationships were highly significant and thus had enhanced the social condition.

\section{Social Impact of Medical Assistance Service}

Medical assistance is the most received and applied for service. People tend to acquire this service either because they do not have excess to the medical aid, or they are short of funds. The following table represents the results between satisfaction level and medical aid

Table 2: Medical Assistance Social Impact

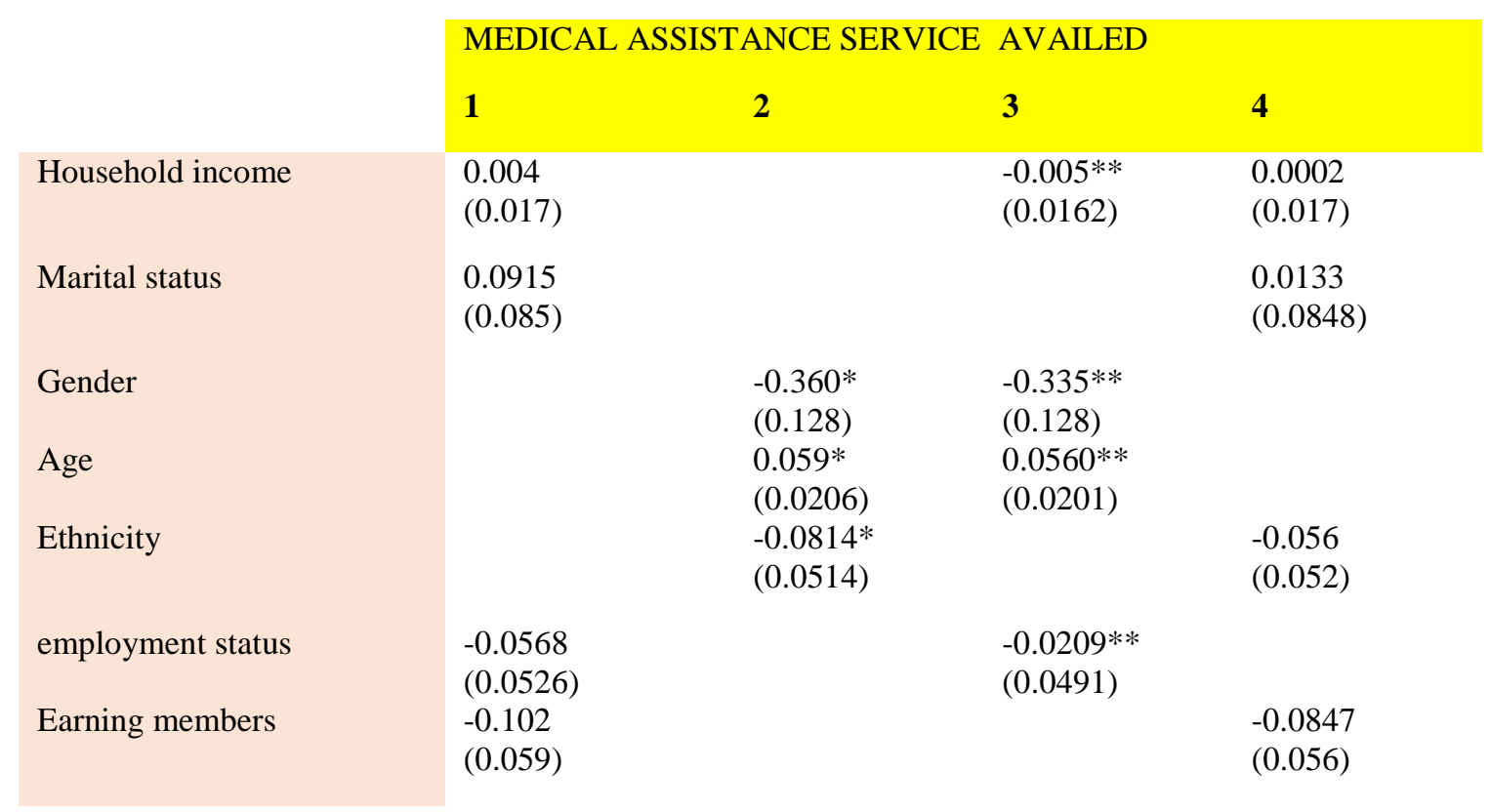

\section{Social Impact of Educational Assistance Service}

It was the second most demanded service. To check the level of satisfaction this service was creating we evaluated through 4 different relationships. All the values turned out to be significant i.e. $p>0.05$ or $\mathrm{p}<0.05$., which shows that these variables had enhanced the social condition of the beneficiaries. Moreover, only one of the four sets of relationship turned out to be highly insignificant and does not having any impactful relationship. The regressed results are accumulated in the following table.

Table 3: Educational Assistance Social Impact

EDUCATIONAL ASSISTANCE SERVICE AVAILED

1

2

3

4 


\begin{tabular}{|c|c|c|c|c|}
\hline Educational level & & $\begin{array}{l}-0.012 \\
(0.0211)\end{array}$ & $\begin{array}{l}-0.142 * * \\
(0.021)\end{array}$ & $\begin{array}{l}-0.012 \\
(0.0218)\end{array}$ \\
\hline $\begin{array}{l}\text { Age } \\
\text { employment status }\end{array}$ & $\begin{array}{l}0.007 * * \\
(0.0156)\end{array}$ & $\begin{array}{l}0.0202 \\
(0.0308)\end{array}$ & $\begin{array}{l}0.0087 * * \\
(0.0161) \\
0.0099 * * \\
(0.0381)\end{array}$ & $\begin{array}{l}0.0202 \\
(0.0387)\end{array}$ \\
\hline Gender & $\begin{array}{l}-0.322 * * \\
(0.0956)\end{array}$ & & $\begin{array}{l}-0.307 * * \\
(0.0935)\end{array}$ & \\
\hline Household income & & $\begin{array}{l}0.0412 \\
(0.0123)\end{array}$ & & $\begin{array}{l}0.0319 \\
(0.0125)\end{array}$ \\
\hline earning members & & $\begin{array}{l}-0.614 \\
(0.0445)\end{array}$ & $\begin{array}{l}-0.0545^{* *} \\
(0.0429)\end{array}$ & $\begin{array}{l}-0.0671 \\
(0.0452)\end{array}$ \\
\hline Marital status & $\begin{array}{l}-0.005 * * \\
(0.062)\end{array}$ & & & $\begin{array}{l}0.0048 \\
(0.0638)\end{array}$ \\
\hline Ethnicity & $\begin{array}{l}-0.0344 * * \\
(0.0379)\end{array}$ & & & $\begin{array}{l}-0.0175 \\
(0.0388)\end{array}$ \\
\hline
\end{tabular}

\section{Economic Impact of Services}

In order to evaluate the economic impact of the service we evaluated that whether the needs and requirements of the beneficiaries were being fulfilled by the programs and services or not. The results revealed to be significant enough in order to enhance the economic conditions of the recipients. Moreover, through analysis it was confirmed that apart from three variable that include type of medical aid, nature of medical aid and nature of medical assistance all independent variables had a positive relationship and were highly impactful. The results are summarized in the following table.

Table 4: Economic Impact of Services

\begin{tabular}{llll} 
& \multicolumn{2}{l}{ DEPENDENT VARIABLE } \\
& NEEDS COVERED & \\
\hline INDEPENDENT VARIABLE & $\mathbf{1}$ & $\mathbf{2}$ & $\mathbf{3}$ \\
Financial aid in PKR & $0.751^{* * *}$ & & \\
Type of medical aid & $(0.0213)$ & $-0.064^{* * *}$ & \\
Nature of medical aid & & $(0.0458)$ & \\
Type of educational assistance & & $-0.133^{* * *}$ & $0.296^{* *}$ \\
& & $(0.074)$ & $(0.121)$ \\
Nature of educational assistance & & & $-0.223^{* *}$ \\
& & & $(0.0751)$
\end{tabular}

\section{Content analysis of interview Background of institution}

PBM was founded in 1992 by the directive of then PM Nawaz Sharif. Having operational social safety nets is a responsibility of the state and also made mandatory under the UN charter. Bait ul Mal's primary function is "shock therapy". A man comes broke and bankrupt without means to support himself, we offer him temporary relief from his indigence so he can buy some time to sort out his matters and arrange provisions for future. We just don't entertain every poor that comes to us, indeed that would be 
impossible. We have set a criterion by which we single out the deserving and non-deserving. Our beneficiaries have to be the poorest of the poor, the lowest stratum of society, and the destitute. We check the following boxes before we enroll a person on our program: (there's no flexibility in this regard)

1. The person should be earning no more than Rs.17, 500 a month.

2. Must not be a government employee.

3. Must not be a pensioner.

4. The applicant must not be receiving donations and charity from any other organization. This we check through a registry that we maintain in collaboration with BISP. That registry is called National Socio Economic Registry (NSER). Data of beneficiaries are recorded in it.

We have ADs (assistant director) in every district of Pakistan and 7 regional offices including GB. The applicant is required to answer 7 to 8 questions that we ask him about his socio economic condition after which we appraise if his deserving status. Our budget is Rs. 5.6 Billion.

There's no major distinction between the domains and areas of responsibilities of PBM, BISP, Zakat Fund etc. since they all work for welfare of the poor but only that PBM is the country's social protection organization. Criteria might differ slightly between these organizations. Bait ulmaal act is laid out in our website that highlights our work and responsibilities. Our widest scope is in education and health sector. We collaborate with INGOs like, WHO King Salman Relief Fund, King Abdullah Relief Fund, Turkish NGO to name a few.

\section{PBM initial remedy for the applicant}

As first step we hand over a cheque of 30-50 thousand to the applicant after formally receiving and verifying his written application. After that we refer him to our assistant director, an officer of BPS-17, stationed in his native district. The district officer then in turn, suiting his own better judgement, visits the dwelling village of the person. We then decide how much amount in cash ought to be given to the applicant depending on a number of factors such as the number of persons dependent on him etc. We handover this cheque once a year to the applicant and this payment comes under General Assistance.

\section{Educational Aid}

We also donate in education sector liberally, giving 50 lacs alone every year to NUST. Similarly, student's father should not be a government employee if he is to receive aid from us. Initially we prepare and investigation report in order to give him eligibility status. We support the student throughout his time in university provided that he does not fail in any course. In case he fails the aid shall be withdrawn. We have signed MoUs with 42 universities in the country. Other than that, we do not deny support to any student who doesn't apply for aid through his relevant university channel. We prefer giving aid to public sector institutes since they maintain higher standards of education and fall under government supervision. Also, private universities have expensive fees. Nevertheless, for future we do plan to extend our aid to private education as well. We currently sponsor 55 students in NUST alone.

\section{Health Sector}

Here we strictly limit our aid to public hospitals. Criterion is the same here as mentioned above. Surgery is usually free of cost in these hospitals, so we provide aid for medical accessories that need to purchase such as stents for heart patients, and optical lenses for the blind or cataracts patients and so forth. We contact the hospital and transfer the amount needed to it via cheque or bank draft. We check the bills and the amount saved is returned to us by the hospital. In case additional funds are needed we also fulfill them on the doctors' recommendations. Here no cash is handed to the patient himself but directly ceded to the hospital. We run joint accounts with the hospitals and on quarterly basis it is audited. We normally fund chronic and mortal diseases like cardiac, kidney, cancer ailments etc. however where there's no treatment of a disease available in public only then we dish out funds to private institutes. In publicprivate partnership the latter lower their prices and do not charge us on market or else that would be 
impossible to meet considering the exorbitant amounts they charge their patients with. Majority of funds go to cancer patients and very recently we have started financing cochlear implants.

\section{Impact on socio-economic condition of beneficiaries}

We have over a hundred thousand beneficiaries currently on our panel. Walk in beneficiaries are countless who receive immediate cash transfers. We keep on supporting them until our annual budget is exhausted. The age bracket of beneficiaries is mostly between 20-40 years, both male and female, which reflects the plight of the young lot in our country. Rural folks come to us a lot more than their urban counterparts since there's more poverty in the villages.

In all honesty with just enough support that we provide to a person who knocks our door as to meet his nutritional needs and clothing, we do not claim to change lives and raise one from rags to riches. As I said its simply shock therapy and only for those who have nowhere else to go. The support is temporary and not for lifetime and if during that period the person does something to alter his fortune for the better, then all the more blessing it'd be for him. While we are sifting through the piles of applications we take notice of points so minute as the persons travelling expenses to the hospital for checkup etc. Baitulmaal has recently been tasked with devising a holistic policy for all orphanages of Pakistan under the prime minister's directive. We also plan to start giving monthly aid to widows with young children to support. We are at present providing vocational training courses to young underprivileged girls instructing them in 16 different trades under a women empowerment program in our centers across the country. We have 160 schools in every district on Pakistan for the rehabilitation of children plagued by the curse of child labor where we give stipend to students admitted and their parents to encourage them to attend school. Having enumerated some of our contributions I believe the greatest impact of PBM considering the scope of its beneficiaries ought to be in the health and education sector.

\section{Other services}

We have shelter homes for the elder citizens and orphans. We run two old homes and 55 orphanages across the country. Although we have been asked to open up more orphanages (which is a costly project), to include greater numbers in our net we prefer granting aid to orphans through their mothers given that they live up to our terms at the top of which is that the child must attend school. We of late conducted a survey for the WHO that was later published by University of Zurich. We also support local NGOs in remote areas who are doing progressive work for their populace.

\section{Recommendations}

Some of the flaws that were determined while talking with the beneficiaries included delay in the transferring of funds to beneficiaries account due to long process of funds allocation. Not only that employees also require certain training in order to create a healthy environment. In detail recommendations are as follows:

\section{Digitalization of application process}

The process of funds transfer can be made speedier by integrating modern means of financing like ebanking in their system. This would greatly alleviate the misery of the applicants and save them a lot of hassle. Just like their employee and beneficiary record keeping system has been digitized, the application process of PBM must also pass through the organizations network. The sluggish process of sifting through applications would be a lot swifter that way.

\section{Employees' exchange programs \& trainings}

The staff underperforming and not living up to the expect standards should receive an official reprimands. If the complaints are recurring this should eventually lead to sacking of the staff member and dismissal from service. Furthermore, employees' exchange programs should be held where PBM officials would work for a while in other similar organizations, within Pakistan or abroad. This would broaden their perspective and train them in innovative skills that they can bring back and apply them in 
PBM.

\section{Conclusion}

As a developing country, Pakistan faces several hurdles that are difficult to overcome, some of which include: high illiteracy rates, sub-par citizen health, overpopulation, and deteriorating living conditions. The utilization of public resources as strategic tools has resulted in poor efficiency and effectiveness of public sector organizations. A devastating lack of investment in public resources has led to the ultimate collapse and deterioration of economic welfare development. At this point in time, welfare in Pakistan is not where it needs to be and as such, there is an increasing need for innovative ideas that can revitalize it from its current state. From the lens of economic and social terms, vulnerability can be linked to societal status, under the umbrella of lacking access to the basic needs and rights of every citizen. Furthermore, vulnerable people have no voice or influence in any decision making or any such related structures. Being both economically and socially weak leads to a vicious circle that is near impossible to overcome and leads such individuals to become truly vulnerable in society.

Under the 1991 Act, the Bait-ul-Mal was established to provide aid to those in desperate need, who on average earn less than 800 Rupees annually. These individuals include disabled individuals, widows, orphans, the impoverished etc. It generated funds through Zakat (Donations) and tax revenue. The administrations rendered by the office contribute towards welfare and poverty alleviation of the under favored and the poor sections of the general public through direct monetary aid and premium free credits, institutional consideration, training and rehabilitation, through budgetary allotments by the legislature and guaranteeing activation of private assets through intentional commitments by enlisted social welfare offices.

Keeping in mind the importance of poverty reduction programs along with other welfare plans as a stepping stone towards the most effective welfare state, the significance of Pakistan Bait-ul-Mal can't be denied and therefore the viability of a lawful sponsorship for such projects or organizations has for quite some time been perceived by the policy makers. The seriousness of the research further enhances because of the way that this subject had not been in the spotlight for quite a long time. Consequently, institutional re-building and approach corrections have not been much into training.

\section{Works Cited}

Abu, T. K. (2014). Disaster Managment in Pakistan . Research Gate .

Adam, H. (2019, April 30). Financial Analysis- Random Sampling . Retrieved from Investopedia : https://www.investopedia.com/terms/s/simple-random-sample.asp

ADB. (2005 ). PovertY Line Analysis. Retrieved from Asian Development Bank : https://data.adb.org/dashboard

Anderson, C. (1979). Political Designs and Representation of Interest. In P. Schimitter, Trends towards corporatist Intermediation (pp. 73-145 ). Beverly Hills, CA: Sage Publications .

Bank, W. D. (2005). Developing Nations Analysis. WDR Reports.

Brunsson, N., \& Olsen, J. (1997). The Reforming Organization. Bergen: Fagbokforlaget. .

Clarke, V. B. (2008). Using thematic analysis in psychology. Qualitative Research in Psychology, 77101.

Dupuy, F., \& Thoenig, J. C. (1985). L'Administration en miettes. Paris: Le Seuil.

GoP. (2002). Labor statistics of Pakistan. Retrieved from Government of Pakistan .

Hamilton, L. C. (1992). Regression with Graphics: A second Course in Applied Statistics. pacific Grove.

Kondra, A., \& Hinings, C. (1998). Organizational diversity and change in institutional theory. In Organizational Studies (pp. 743-67).

mailman.columbia. (n.d.). Retrieved from Population of Health Methods: https://www.mailman.columbia.edu/research/population-health-methods/contentanalysis\#: :text=Content\%20analysis\%20is\%20a\%20research,qualitative\%20data\%20(i.e.\%20te 
xt).\&text=Researchers $\% 20$ can $\% 20$ then $\% 20$ make $\% 20$ inferences,time $\% 20$ of $\% 20$ surrounding $\% 20$ the \%20text.

March, J., \& Olsen, J. (1975). The uncertainty of the past: organizational learning under ambiguity. European Journal of Political Research, 174-71.

March, J., \& Olsen, J. (1976). Ambiguity and Choice in Organizations. Bergen: Universitetsforlaget..

March, J., \& Olsen, J. (1984). The New Institutionalism: organizational factors in political life. American Political Science Review , 734-49.

Meyer, J., \& Scott, W. (1983). Organizational Environments: Rituals and Rationality. London: Sage .

Mohamed Elfil, A. N. (2017 ). Sampling methods in Clinical Research; an Educational Review. PubMed Central NCBI.

Pakistan, u. D. (2019). ReliefWeb. Retrieved from OCHA services: https://reliefweb.int/report/pakistan/multidimensional-poverty-pakistan

(2005 ). PMDGR. Pakistan Government.

Selltiz, C. (1962). Research methods in social relations . NewYorkRinehart and Wineston.

Selzinick, P. (1948). Foundations of The theory of Organizations . American Sociological Review, 2535.

Selzinick, P. (1949). TVA and Grass Roots . Bercley, CA . 